\title{
FOCUS
}

\section{MERMAIDS IN THE LAND OF THE KING: AN ETHNOGRAPHY OF SANTOS FC WOMEN}

\author{
AS SEREIAS DA VILA NA TERRA DO REI: UMA ETNOGRAFIA DE \\ SANTOS FC FEMININO C
}

LAS SIRENAS DE LA VILLA EN LA TIERRA DEL REY: UNA ETNOGRAFÍA DEL SANTOS FC FEMENINO C己

doi' https://doi.org/10.22456/1982-8918.109357

Mark Daniel Biram* <mb17689@bristol.ac.uk>

*Universidade de Bristol, Bristol, Reino Unido, UK.

\begin{abstract}
Based on three-months ethnographic fieldwork spent with the Santos FC women's team, this article considers how women players negotiate the tensions between the club's invented gendered tradition and their formal inclusion into the club. Using Hobsbawm's concept of Invented Traditions and adapting Billig's banal nationalism to banal patriarchy, the article explores the experiences of women players within one of Brazil's most emblematic clubs. Whilst men no longer have a monopoly on officialised club football, the article concludes that incorporating the accrued cultural capital of women's football at clubs like Santos is vital to dislodge and de-stabilise the perceived masculine tradition and history of the club.
\end{abstract}

Keywords: Football. Research report. Ethnography.
Received: 23 Nov. 2020 Accepted: 10 Dec. 2020 Published: 05 Jan. 2021

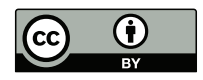

This is an article published in open access under the Creative Commons Attribution 4.0 (CC BY 4.0) eISSN: $1982-8918$ 


\section{INTRODUCTION}

As I walk towards Santos FC training ground I see several murals commemorating the rich tradition of the club and its importance in establishing Brazil as the country of football (HELAL; SOARES; LOVISOLO, 2001; BOCKETTI, 2016; GOLDBLATT, 2014; KITTLESON, 2014). I am particularly taken with a quote from the great Brazilian poet Carlos Drummond de Andrade which says "the most difficult thing is not, in fact, to reach a thousand goals as Pelé did, but rather to score just one (with the style) of Pelé". With Pelé unambiguously on a pedestal above all mere mortals, I wonder: what space is there for women to dislodge such mythology and establish themselves within the discursive tradition of these clubs? The question of how women's contributions to Brazilian club football can be recognised and incorporated into hyper-masculinised club discourse and tradition has been neglected thus far. This article begins to address that lacuna by arguing that Santos FC is actually a fine example of a club where the cultural capital of women's football could be more significantly incorporated into the club's discursive tradition.

As I finally negotiate my way past security I am greeted by my contact: general manager (for women's football) Alessandro Pinto. He introduces me to some of the players who have arrived early for training. I meet Erikinha, Sandrinha and Kelly Rodrigues briefly as they warm up ready for training. Just before the session begins, I also glimpse Rosana dos Santos Augusto. I momentarily feel slightly starstruck to see a player who has contested World and Olympic finals. With none of the reticence and apprehension of the other players she greets me in confident English and immediately enquires as to what exactly I am doing here. Rosana quickly disappears with the air of someone not given to wasting time. I notice other faces I recognise - Maurine, a player of similar pedigree. Next I recognise Ketlen, who despite little fanfare, has since gone on to become Sereias all-time leading scorer and first player to score 100 goals. This underplayed achievement reminds me that whilst it is well-documented that the Santos of Pelé were the first Brazilian club to win the continental title (in 1962 and 1963), it is less well-known that the Santos of Marta was the first Brazilian club to win the women's equivalent in 2009 and 2010 (RIAL, 2013)1.

\subsection{THE LAND OF THE KING (CT REI PELÉ)}

Nearing the conclusion of the session at the King Pelé training ground (CT Rei Pelé in Portuguese) another animated discussion between backroom staff ensues with players clearly within earshot. A congested and disjointed end of regional, national and continental competitions awaits. In just one week, they will face Corinthians in an evenly balanced two-legged final of the Paulista Championship 2018. With barely time to draw breath, Sereias da Vila then travel almost 4,000 kilometres to Manaus for the Copa Libertadores tournament in November $2018^{2}$.

\footnotetext{
1 Marta Vieira da Silva is the only player to win the FIFA World Player of the Year award six times. Ketlen Wiggers, Maurine Gonçalves and Kelly Rodrigues were each part of the Santos FC Women 2009 and 2010 school which won the Libertadores tournament.

2 Santos Women had won the Brazilian championship in 2017 to earn the privilege of representing Brazil at the continental tournament.
} 
Watching the hi-tech nature of a training session here, it is clear the infrastructure here is on a different level to the other clubs I have visited. I am told the facilities match any available elsewhere in Brazil and probably across the entire continent. Whilst a variety of cutting-edge training techniques take place, a number of drones fly disconcertingly above our heads assisting the computerised devices attached to each player to monitor their individual daily performance across a range of metrics. The pristine surface of Santos' training pitch feels is befitting of an ensemble of top-level professional women footballers, many of whom have accrued a range of experience across both nationally and in many cases beyond. The King Pelé Training Ground has three pitches with official dimensions. The first is the smallest pitch, used largely for youth matches with space for up to 5,000 spectators. The second intentionally has the same dimensions size as the Vila Belmiro (Santos' stadium) while the third matches the size of the municipal Morumbi in São Paulo. The impressive facility even includes a five-star hotel where the Santos (men's) first-team often stay before big games, and a sizeable purpose-built space where journalists are able to conduct interviews and press conferences with the players in a professional environment. Beyond the training facilities, way in the distance is a steep incline scattered with precarious tenement style housing stacked one on top of another. The view from the comfortable confines of a complex guarded by numerous security staff typifies the stark social divide which characterises the country and, in various and often unacknowledged ways, foregrounds many of its social interactions.

An escalation in the initially good-humoured discussion diverts my attention back to the issue at hand. Team manager Emily Lima and some of the players appear somewhat irate. It appears that after just three days training on the impeccable surface at the CT Rei Pelé, the women are being moved on to make way for the discursively legitimate custodians of the Kings' quarters - Santos FC (men). I wonder momentarily if I am missing something on account of my floundering Portuguese. I confirm I heard correctly whilst endeavouring not to look too obviously aghast or surprised. With the quality of the facilities and the number of pitches available there seems no rational reason why both the men and the women could not train here simultaneously or, if necessary, be scheduled at different times of the day. Nonetheless, the prevailing power relations here seem still to not only negate this possibility but render the suggestion of outright equality unconscionable. There was no mistake. It is patently clear that football is a world removed from other social interactions (which are also problematically gendered, but less so). Football remains an area so eminently masculine that this type of vulgar gender differentiation is often hidden in plain sight, not even acknowledged by those perpetrating it, although they surely know. The return to a status-quo where the women's team are sub-categorised at the same level as children within the club is symptomatic of this.

\subsection{THE LAND OF THE KIDS (CT MENINOS DA VILA)}

For the time-being, it would appear, Santos Women are being moved back to where I am told they spend most of their time - CT Meninos Da Vila (Vila Belmiro Boys' Training Ground). Whilst some of the players clearly recognise this as a 
demeaning affront trivialising their hard-earned status as professional footballers, there is also a sense of common-sense resignation which is underpinned by the club's own insidiously patriarchal self-presentation and organisation. I have heard plenty, in confidence, about these facilities. The grass tends to be a few centimetres or even inches longer. They warned me the surface was full of bobbles, causing unpredictable bounces on the ball, or much worse, a higher likelihood of incurring injuries.

Upon arrival I realised immediately that, if anything, my informants had understated the case. The facilities at Meninos da Vila are rustic at best. The training pitch has the kind of surface upon which technical training on cohesive zippy passing are out of the question. This inevitably further stymies the development of players who often started later and with less infrastructure and facilities available than their male counterparts in the first place. Many of the players touch appears a little more erratic than when they were training at the King's training ground. The exceptional players are still able to pull off the difficult touches - Maurine manages a perfect lob over the keeper at pace and then nonchalantly wheels away as if nothing happened. She tells me later in an interview that, like so many of her generation, she grew up playing alongside boys on far worse surfaces in her native Rio Grande do Sul.

Emily Lima, noting my downcast countenance, is quick to do what comes naturally to her every day in her job. She turns a negative into a challenge or into something which would have some value in the longer term. She told me it was a good thing that I would see the full reality of Santos FC and not a falsely tamed experience designed to impress a visitor. Lima, I realise early on, is intent on ensuring just this happens and is always forthright and sincere about the things the club does right and those which she would change tomorrow given the chance. The dissatisfaction with the situation at Santos owes much to knowing that it does not have to be this way at such a well-resourced club. These are political decisions made within the club and it could be stopped immediately were there sufficient political will to do so. The players play their part, keeping the club, regional and national hierarchies under pressure in numerous ways, but the final decision still disproportionately rests with people distant from their reality. Despite undeniable strides made by women's football in recent years, in terms of priority at club level, professional grown women players are placed on a par with boys as young as eleven. I wonder what are the meanings and power relations which have naturalised and legitimised such obvious gender differentiation? What are the players' lived experiences and impressions of this state of affairs? How have they contested it thus far bringing us to the point we are at today?

\section{THEORETICAL FRAME}

At a quieter moment some weeks later coach Emily Lima would make an incisive passing remark which stayed with me. Lima noted that women's football is always seen as something additional artificially grafted onto the deep-rooted tradition perceived and portrayed as all-important. My contention in this article takes note of this by exploring an unacknowledged tension at play - the way in which the agenda for equality is significantly encumbered by the rootedness of banal patriarchy within 
clubs. This tends to dilute equality into something far less radical, more akin to inclusion (ELSEY; NADEL, 2019, p. 10).

\subsection{BANAL PATRIARCHY}

It struck me during fieldwork that many of the rooted attitudes and practices at the club often manifest themselves in banal and often unperceived ways, akin to Michael the concept of banal nationalism introduced by Billig (1995). For example the countless references to being bi-champions of the world on club merchandise or commemorated by two stars above the Santos club badge ${ }^{3}$. Billig's concept refers to everyday representations of national symbolism which contribute in often unacknowledged ways to buttressing a shared sense of national belonging. This concept lends itself well to football fandom, which is also rooted in collective identity. In this sense, this article registers less visible, everyday forms which are deeply ingrained and in insidious ways contribute more to upholding a gendered social order than more extreme or overt outbursts of sexism. These expressions of what I call banal patriarchy feed into a wider invented or at least embellished masculinised tradition which upholds a gendered social order. Female participation in football, by definition, subverts this, but the manifest imbalances provoked by a lack of female representation in positions of power mean banal patriarchy and the perceived masculine hegemony over club football can only be eroded gradually, particularly as much of the presence is unacknowledged.

\subsection{THE SANTOS FC INVENTED TRADITION}

To conceptualise the longevity and deep-rootedness the club discursively presents, Hobsbawm's notion of invented traditions is insightful as a theoretical frame. This will help explain away the selective omissions, inclusions and embellishments of the club's history. This discourse, clearly, is subject to analysis, contestation and reshaping from a range of interested actors. As Hobsbawm (2012, p. 1) argues "traditions which appear or claim to be old are quite often recent in origin". This is arguably the case with Santos FC. As of 2020 the club is 108 years old, having been born in 1912 within hours of the sinking of the Titanic. Hobsbawm's conceptualisation of invented traditions incorporates "traditions formally instituted within a brief and dateable period which establish themselves with great rapidity". He continues to state that they are "often of a ritual and symbolic nature, which seeks to inculcate certain values and norms of behaviour by repetition, automatically implying continuity with the past".

In this vein, much of the mythology dates back only as far as the period in which Pelé starred for the club, largely in the 1960s and 1970s and not beyond the length of a century as club discourse would have us believe. This was concurrent and interrelated with the establishment of Brazil as the gold standard of men's football. Counting these friendlies, often against non-professional opposition in novelty matches, King Pelé scored over a thousand goals for Santos FC - a round figure often invoked to prove his superiority over other football legends (GOLDBLATT, 2014; KNIJNIK, 2018).

\footnotetext{
3 Similarly for many years the Brazilian women's national team played with five stars above the club insignia commemorating five men's World Cups. In the case of Santos' two "World" championships, this in reality commemorates an intercontinental play-off including only Europe.
} 


\subsection{THE OBSCURED TRADITION - WOMEN'S FOOTBALL AT SANTOS FC}

The previous section explained how the masculinised tradition at Santos FC is discursively rooted in a relatively short period whilst insinuating itself to have a far longer history (HOBSBAWM, 2012). Similarly, the gendered tradition is accentuated by systematically obscuring the hidden history of women's football in Brazil, thus encouraging the misconception that women's football is something relatively new against a long tradition of men's football. A growing body of work recuperating the hidden history of women's football in Brazil (FRANZINI, 2005; GOELLNER, 2005; SALVINI; MARCHI JÚNIOR, 2013) and elsewhere on the continent (ELSEY; NADEL, 2019) emphasises these historical and structural injustices. For example, in 1941, the Conselho Nacional de Desportos (National Council for Sports) instituted Law 3.199. This legislation was fundamental in delimiting the sporting order for decades to come. One of its articles established the prohibition of female participation in various sporting activities, including football. This pernicious decree lasted until 1979. Whilst part of the embellished tradition of the club is trying to elongate its glory period, realistically the main golden period of Santos, upon which its embellished tradition is based, occurred while women's football was prohibited and from 1964 onwards under military dictatorship.

Nevertheless, it does not take much digging below the surface to realise that Santos Women have accrued plenty of their own cultural capital which could easily be highlighted more if the political will existed within the club. Structural inequalities often mean that the club's significant women players often spend less time with the club before flying the nest. Nonetheless, a significant step forward would surely be acknowledging the protagonism of women players and the significance of Santos in giving the Brazilian national team a base from which to build. From the team which reached Olympic and World Cup finals, Marta, Cristiane, Maurine, Aline Pellegrino, Érika and Maurine gained valuable competitive and formative experience with Santos. This is to say, Santos could easily note the symmetry of having had arguably the bestknown male and female player having played for them. Marta even achieved significant honours for the club forming part of the Santos squad that won the inaugural Copa Libertadores tournament ${ }^{4}$.

Traditions, imagined or otherwise, accrue currency over a period of time. In 2020 it is abundantly clear that Santos FC is still imagined within the club as a masculine space, to which as Emily Lima suggests, the women's team is merely a precarious appendage. There are certainly precedents in the club's recent history which suggest Lima's analysis is not an opinion but a fact. In 2012, Santos Women were performing well on a national and continental level. They had won the 2009 and 2010 Copa Libertadores and finished 3rd in the 2011 edition. They were reigning Paulista champions. The club's response to this success was to produce a raunchy calendar of the women's team, ostensibly to make the players "more marketable" (JORAS, 2015, p. 84) before proceeding to disband the team just three days after the calendar finished in 2012, coinciding with efforts to retain Neymar (GOLDBLATT, 2014; KNIJNIK, 2018).

4 Marta has won the world player of the year award six times and has scored more goals than anyone (male or female) at World Cup tournaments. 
In spite of the club hierarchy consistently undervaluing women's football, it does has a particular pull at the Vila Belmiro since the inaugural Women's Copa Libertadores was held in this stadium. They brushed aside rivals from across the continent scoring 42 goals and only receiving two across only six games. Large local crowds flocked to these games as Marta, at that time, was the reigning world player of the year, with Cristiane also nominated in the top three in the world. It is lamentable that this accrued social capital is not celebrated more. It is symptomatic of the sub-categorisation of women's football and of the threat having another continentconquering team poses to the deeply masculinised invented tradition of the club.

\section{METHODOLOGY}

This article is based upon three months ethnographic fieldwork spent with Santos between October 2018 and February 2019. The results section presents several vignettes capturing episodes symptomatic of the strength of the masculinised invented tradition of the club and places them in tension with the everyday experiences of players. Owing to space, this article offers an abridged version of a full ethnographic account. It differentiates between how on the pitch and the training ground the players, by definition, are able to challenge hegemonic representations by emphasising athletic performance. Off the pitch the players are still deployed to promote a gendered vision in keeping with the club hierarchy's sexualised branding of the club as Sereias da Vila. Each episode is coloured by the unacknowledged influence of the club's invented tradition. For example, even the club's own branding has sought to feminise the team as sirens or mermaids, differentiating them from the hegemonic male version of the team. The gendering choice of Sereias as the team name is telling. Sereia is defined in the dictionary as being "from nordic mythology, a mytical sea creature with the head and trunk of a woman and the tail of a fish, conventionally depicted as beautiful with long flowing Golden hair" (OXFORD, 2020) or more figuratively as "any very attractive woman" 5 (MICHAELIS, 2020). In both definitions there is a clear focus on the physical appearance of women which continues a long tradition of the objectification of women playing football (BONFIM, 2019).

\section{RESULTS AND DISCUSSION}

The following section is separated into two parts - firstly the way the club represents women footballers - this is shown considering how the club organised the women's Paulista Final and two off-the-field commitments for Santos FC Women. Secondly, it considers how players' agency from their behaviour on the training ground to their involvement in formal and informal activism all goes towards proffering a significant discursive challenge to the aforementioned gendered representations from the first part.

\subsection{WOMEN'S PAULISTA CHAMPIONSHIP FINAL}

Upon my arrival the team faced an important end of season challenge - the final of the 2018 Paulista championship, predictably against Corinthians. The players

5 Original quote: "qualquer mulher muito atraente". 
placed particular importance on this game, as it marks the end of an unwieldy tournament with two group stages, which were routinely dismissed as a "phoney war". Corinthians' and Santos' goal differences of +36 and +37 from a group of just seven teams suggests there have been a lot of dead rubber games. The players complain about this as they realise that the lack of truly competitive games is detrimental to their development.

The much-anticipated final was played over two games. The first game was played at Santos' Vila Belmiro stadium with the decisive second leg played at Parque São Jorge, part of Corinthians training facilities. Both games were free to the public attracting considerable crowds ${ }^{6}$. The game in Santos attracted the larger crowd with 13,867 . This was a record for the Women's Paulista Championship. Players felt that this reflected improved efforts on the part of the club to publicise the game and the level of interest in equally balanced games. All over Santos in the week before the game there were posters and flags advertising the game.

During half-time, rather than concentrate on the game, some of the Santos substitutes are made to shoot numbered balls out into the crowd. Each number wins a prize. The prizes are tickets to a Santos men's game, a Santos men's shirt signed by the players, three visits to the King Pelé training ground, various club merchandise and then almost as an afterthought a signed Sereias da Vila shirt. Rather than taking the opportunity to promote solely the women's team at the Sereias game, the players are reminded once again that they are a sub-category of the club. It appears a small detail - perhaps going unnoticed by some fans, but the players' faces tell a story. Clearly, with the women's games structurally obligated to be free, it is not possible to offer tickets for the women's games as a prize. The occasion could have been used to celebrate a tournament which is much coveted by women players on the continent. Instead, this small detail concentrated on the tradition than fans are more familiar with - with a visit to the King's training ground and tickets to see the men play. The way the game is used as a sideshow with which to promote upcoming men's games detracts from the importance of a final. Nonetheless, Sereias da Vila would go on to win a joint-record fourth Paulista title, bringing them level with Juventus da Mooca and Ferroviária.

\subsection{SEREIAS DA VILA IN THE COMMUNITY}

Like most Brazilian clubs Santos is involved in the community in which it operates. The following section covers two initiatives - a visit to an NGO called Recycled Lives and a project to promote girls playing football called Girls on the Pitch.

\subsubsection{Recycled Lives (Vidas Recicladas)}

Early during my visit I was invited to accompany the players to an engagement with Vidas Recicladas (Recycled Lives). Vidas Recicladas is an NGO which takes in (often-abandoned) street children for a period of time, and offers them wide-ranging psychological, emotional, social and economic support. Several women players are

6 Clubs are unable to charge for games in the Paulista Championship as it attracts funding from a federal program fomenting the practice of sports, the Lei de Incentivo ao Esporte. 
enlisted to visit a large home in the city of Santos, where interviews will be carried out for television and photos will be taken for the press. Some players are more inclined than others to participate and say a few kind words. Others appears a little overwhelmed by the experience. Most of the larger Brazilian clubs now have active CSR policies or are aware of the need for the club to undertake a social role within the communities in which they operate. From the players' perspective, on one hand, visits like this are felt on a personal level particularly for players who have grown up in difficult circumstances.

Engaging in community work of this nature clearly has a function and gives something back to the community which makes Santos the large club it is. Nevertheless, I ask myself if this particular activity is knowingly or unknowingly rooted in gendered thinking. Perhaps perceptions of traditional gender roles were taken into consideration when choosing to send the players to a home of orphaned children. Equally, maybe it could just as easily be the men's team who were here. Nevertheless, in the absence of sufficient exposure which highlights the women players as athletes, this type of work could be the only television viewers or newspaper readers see of the players - and thus inadvertently it could reinforce gender stereotypes rather than challenge them. In defence of the club, players were involved in a number of other events which were more directly related to their athletic performance and fomenting the notion of women as athletes.

\subsubsection{Girls on the Pitch (Meninas en Campo)}

In this vein for example, I was also attended an event where Santos FC signed an agreement together with the University of São Paulo and the Girls on the Pitch project (Meninas em Campo) committing the club and its partners to help develop female players in the 11-17 age range. Without doubt this places Santos FC as a pioneer offering provision for these age groups. Elsewhere, this type of initiative remain almost non-existent. This reminds me of various players' comments. Tayla, for example, casually explained she is the "typical" example of a player who learnt her trade playing on the streets.

From one perspective I am clearly receiving a sanitised version of Santos FC but from another it is clear that there is a progressive force that is pressing larger clubs like Santos into taking some of the necessary steps to grow youth team football for Brazilian girls. There is a possibility this type of initiative will have a snowball effect as competing clubs do not wish to allow Santos an easy propaganda victory. The competitive instinct of clubs in not allowing their rivals to achieve something before them may cause further positive action. In this regard, Santos are to be congratulated for pushing this initiative - they were the first to do so and were not cajoled or blackmailed into doing so. This reminds me that each club, even when they have an embellished tradition which systematically privileges masculinity, is influenced by progressive actors inside and outside who push quietly for this type of gradual progress. The project places emphasis on social formation as well as football, an aspect which has traditionally been much neglected during the growth periods in men's football. Beyond this it is an area which is of fundamental importance given the backgrounds 
many of the players come from. A football career is relatively short and there are no guarantees of further employment after finishing as a player - particularly for women, who until recently have been systematically excluded from coaching roles in the game. Again, Santos uses the players to promote itself as a progressive institution. On this occasion it is laudable but again is outside of promoting the players' athletic performance - the area which truly undermines and/or destabilises male hegemony. My time with the players on the training ground gave me the strongest indication of the plural realities of women's football, outside of cliched representations.

\subsection{SEREIAS ON THE TRAINING GROUND}

Each morning on the training ground there is an atmosphere of joviality. Thus far, club engagements have seen the women presented as a sub-category of the men's team. Indeed, even at their own matches women players were used to hand out prizes largely connected with the male team.

These clear attempts to differentiate and present the women's team as qualitatively divergent from the men's team defends hegemonic masculinity (CONNELL, 1993). In the words of Butler (2011, p. 17) "the cultural matrix through which gender identity has become intelligible requires that certain kinds of 'identities' cannot 'exist' - that is, those in which gender does not follow from sex and those in which the practices of desire do not 'follow' from either sex or gender". This explains the playing down of players' athletic performativity. It explains why the club invites prize-winners to see the men train but not the women. In this vein, the following sections highlight how the everyday behaviour, self-image and aspirations of the players present a more heterogeneous picture of reality, breaking with cliched feminised narratives and thus, if given due attention, have the potential to de-stabilise dominant gender binaries.

From the outset, numerous players are larking around prior to the commencement of the training session. One of the players gleefully blasts a ball as hard as they can at the back of another player's head to uproarious laughter. The lack of surprise suggests this kind of juvenile antics happens quite often. There are 34 players in an unwieldy Santos squad - a mix of highly established internationals who have plied their trade in other countries, players with a solid reputation within Brazil and hopefuls who aspire to break into the first team and make a career from the game. Many of these hopefuls have been uprooted from their home states to try their luck at Santos. There are clearly cliques within the group whereby the more established exude self-confidence whereas others know their future is far from guaranteed. Some of the veteran players take the time to help integrate the newer ones and offer them someone to confide in when things get difficult.

Whilst at the Copa Libertadores tournament in Manaus the players' training was based at the facilities of $3 \mathrm{~B}^{7}$. There is an atmosphere that is slightly different. The change of environment is a double-edged sword. The players each try to feign the calm that is needed at a large tournament. Equally, the team is genuinely enjoying being away from home in a continental tournament. The players laugh and joke

7 3B is the Manaus based team of Dom Bosco Brasil Bindá. He lent his facilities to teams competing in the 2018 Copa Libertadores in Manaus. 
through the session. Notably, at the end they ambush the club's Press Attaché Vitor Anjos. Four or five players grab Anjos before taking out a razor and forcibly shaving off his moustache. Anjos struggles briefly in between laughing before realising he has little chance, being overpowered by five or six players. A few minutes later he is left half-shaven looking somewhat ridiculous. The players explain that this was an agreed penitence of a bet they had (and won) with Anjos. Anjos shakes his head and tries to look surprised or upset. The players are no shrinking violets and are prepared to stand up for themselves. This again seems to typify how distant the reality of the players is from the hyper-feminised club representations of the Sereias. Indeed, the everyday atmosphere with the players is more akin to the detailed description offered by Hunter Davies in his seminal text The Glory Game (1973), after spending a period of time with Tottenham Hotspur in the 1970s. The training ground performance is just that a performance. It is not necessarily representative of how the players would ideally behave as individuals, however it does represent the way they choose to present themselves on the training ground as a collective. They present themselves as tough but with a sense of humour. In the case of some players, it is only when they are isolated in a different setting for interviews that they break with the matrix of behaviour expected on the training ground. Nonetheless, it is noteworthy that the tone for this expected behavioural pattern is set by the players themselves.

\subsection{COLLECTIVE STRUGGLE ON AND OFF THE PITCH}

Football, by its nature, offers varying levels of job stability dependent upon previous experience and accrued agency within the game. Goalkeeper and Activist Thais Picarte is the first to admit that the conditions at Santos are superior to those at many other clubs in Brazil in this regard, however she continues working tirelessly for players across the region. Picarte is a director for the FENAPF (National Federation of Professional Athletes and is also the Vice-President of SIAFMSP (The Union of Professional Athletes for São Paulo). Beyond this she is involved in the Guerreiras project. Guerreiras is an international movement aimed at fomenting gender equality and challenging discrimination by bringing together activists, academics and athletes (ANJOS et al., 2018).

In her work for FENAPF Picarte is engaged in the gradual struggle to professionalise Brazilian women's football. Despite rhetoric to the contrary, Picarte is quick to underline how the Brazilian tournament, whilst improving, is still a long way from being a professional tournament. It allows amateur teams to compete, some of whom pay the players badly if at all. Picarte laments how only two teams - Santos and São Paulo - entirely register their players, allowing them to accrue pension benefits and suchlike. Others tend to only register certain star players and then fill up the rest of the squad with amateurs. This type of practice is clearly divisive and has the effect of diverting players from their common interest. Picarte is absolutely clear that the common interest must come first. She realises that whilst elite players can forge a more comfortable career outside Brazil, that the great majority of Brazilian women players are subject to the conditions within the country. Picarte believes firmly that the debate in Brazil has moved on. She summarises that it is now much less about "being 
a lesbian or not" and she argues that prejudice has taken refuge in the logic of the market. Contractual conditions have remained stagnant for two decades she argues, with the justification always being the vicious circle that claims women's football does not generate sufficient income as it is never promoted enough to do so.

On the training ground there is appreciation of the type of work Picarte does, but also a barely disguised trepidation as to how such activism would be perceived were younger players to get involved. Similarly, players often cite the advances made to the Paulista tournament under the control of ex-Santos player Aline Pellegrino. Regarding union struggles, it is difficult to build the level of solidarity necessary with players, on one level, competing with one another for short flexibilised contracts. Conversely, given the divisive contractual situation, the sense of solidarity between the players is all the more admirable. Many of the players know that they are ultimately playing a long game and that real change will only come with further representation from ex-women players and/or more allies on both the boards of federations and clubs.

\section{CONCLUSION}

This article has considered how the rootedness of male hegemony affects everyday practice within one of Brazil's prestige clubs Santos FC. It has argued that the omnipresence of banal patriarchy within the club has meant that the incorporation of women's football has always felt like - in the words of Emily Lima - "something extra grafted onto the male tradition" of the club. The strength of male hegemony largely personified by the King Pelé - means that even a women's team which has achieved significant honours and is a pioneer at a national and continental level is barely incorporated into the club's mythology. The strength of the Santos FC invented tradition is such that using the women players to hand out prizes to watch men's games is seen as banal rather than overtly discriminatory or demeaning. Similarly, reserving the best training facilities for the men's team and sending the women's team to train with children is also seen by some as a normalised occurrence rather than plainly prejudicial. On the other hand, the women's team are habitually given "equal opportunity" when it comes to promoting Santos in the community. Indeed, duties involving children seem to be disproportionately allotted to the Sereias.

The second part is symptomatic of how the players proffer two challenges to male hegemony - firstly through their athletic performance which inherently destabilises the matrix. By being involved in a sphere still seen as eminently male, they inherently weaken certain limits of an activity seen as exclusively male and they also break with the idealised image of femininity which the club attempts to present with its Sereias branding. Secondly by continuing to campaign for further recognition through activism. Players are achieving representation at federation level, within clubs and on the coaching side of their respective clubs. The previous couple of decades have seen women gain a toehold within Brazil's clubs, through the policy requiring clubs to have a functioning women's division/team and through societal pressure and the players' own efforts. For this to become further consolidated clubs will need to proactively incorporate women players into their discursive mythology. One of the clubs 
where this is most feasible is Santos, which has in some sense been more proactive than other clubs in the past couple of decades. Nonetheless, their significant role in providing players to the Brazilian national team which reached Olympic and World Cup finals are significantly underplayed. Instead of being emphasised as outstanding achievements of a generation that achieved so much with so little, women players are ignored at the expense of the hegemonic masculinised tradition.

When I spoke to Angelina Costantino, an 18-year old prodigy who is already a first-team regular for Santos and a fixture in Brazil's under-21 setup, she inversed the habitual pessisism about the potential of women's football asking me to imagine how much Sereias had achieved in spite of all the barriers and wondered just how much further they could go with the right conditions. Revealing of both the barriers that remain and of the potential of the women's game, Angelina asked rhetorically "imagine how popular we could be if we were treated equally". Tellingly the rhetorical question had a conditional structure that suggested it was not on the cards in the foreseeable future, however, it did seem symptomatic of a newly emboldened type of player, benefitting from the struggles of the previous generation.

\section{REFERENCES}

ANJOS, Luiza Aguiar dos. et al. Guerreiras Project: futebol e empoderamento de mulheres. Revista Estudos Feministas, v. 26, n. 1, e44154, 2018. DOI: https://doi.org/10.1590/\%25x

BILLIG, Michael. Banal nationalism. London: Sage, 1995.

BOCKETTI, Gregg. The invention of the beautiful game: football and the making of modern brazil. Gainesville: University Press of Florida, 2016. DOI: https://doi.org/10.2307/j. $\underline{\mathrm{ctvx} 06 \mathrm{xmt}}$

BONFIM, Aira. Football Feminino entre festas esportivas, circos e campos suburbanos: uma história social do futebol praticado por mulheres da introdução à proibição (1915-1941). 2019. 213 f. Dissertação (Mestrado) - Escola de Ciências Sociais da Fundação Getulio Vargas, Programa de Pós-Graduação em História, Política e Bens Culturais, Rio de Janeiro, 2019.

BUTLER, Judith. Gender trouble: Feminism and the subversion of identity. New York: Routledge, 2011.

CONNELL, Robert. Masculinities. London: Polity, 1993.

DAVIES, Hunter. The glory game. London: Random House, 1973.

ELSEY, Brenda; NADEL, Joshua. Futbolera: A History of Women and Sports in Latin America. Austin: University of Texas, 2019.

FRANZINI, Fábio. Futebol é "coisa para macho"?: Pequeno esboço para uma história das mulheres no país do futebol. Revista brasileira de história, v. 25, n. 50, p. 315-328, 2005.

GOELLNER, Silvana Vilodre. Mulheres e futebol no Brasil: entre sombras e visibilidades.

Revista Brasileira de Educação Física e Esporte, v. 19, n. 2, p. 143-151, 2005. 
GOLDBLATT, David. Futebol Nation: A footballing history of Brazil. London: Penguin, 2014.

HELAL, Ronaldo; SOARES, Antônio Jorge Gonçalves; LOVISOLO, Hugo. A invenção do país do futebol: mídia, raça e idolatria. Rio de Janeiro: Mauad, 2001.

HOBSBAWM, Eric. Introduction: The Invention of Tradition. In: HOBSBAWM, E.; RANGER, T. The invention of tradition. Cambridge: Cambridge University, 2012. p. 1-16.

JORAS, Pamela Siqueira. Futebol e mulheres no Brasil: a história de vida de Aline Pellegrino. 2015. 128 f. Dissertação (Mestrado) - Programa de Pós-Graduação em Ciências do Movimento Humano, Escola de Educação Física, Fisioterapia e Dança, Universidade Federal do Rio Grande do Sul, Porto Alegre, 2015.

KITTLESON, Roger. The Country of Football: Soccer and the making of Modern Brazil. Berkeley: University of California, 2014.

KNIJNIK, Jorge. The World Cup Chronicles: 31 Days that Rocked Brazil. Sydney: Fair Play, 2018.

MICHAELIS. Michaelis Dicionário do Português Brasileiro. Available at: http://michaelis. uol.com.brl. Accessed: Aug 10, 2020.

OXFORD. Oxford English Dictionary. Available at: https://www.oed.com/ Accessed: Aug 10, 2020.

RIAL, Carmen. El invisible (y victorioso) fútbol practicado por mujeres en Brasil. Nueva Sociedad, n. 248, p. 114-126, 2013.

SALVINI, Leila; MARCHI JÚNIOR, Wanderley. Uma história do futebol feminino nas páginas da Revista Placar entre os anos de 1980-1990. Movimento, v. 19, n. 1, p. 95-115, 2013. 
Resumo: Baseado em três meses de pesquisa de campo com o time feminino do Santos Futebol Clube, este artigo considera como as jogadoras negociam as tensões entre as inventadas tradições de gênero e a inclusão feminina no clube. Usando o conceito de Hobsbawm de Tradições Inventadas e adaptando a noção desenvolvida por Billig de Nacionalismo Banal para a ideia de Patriarcado Banal, o artigo explora as experiências de jogadoras com um dos mais emblemáticos clubes do Brasil. Enquanto os homens deixam de ter o monopólio dos clubes oficiais de futebol, esta pesquisa conclui que a incorporação do capital cultural acumulado do futebol feminino a clubes como Santos é imprescindível para desestabilizar a percepção de tradição e história somente masculina dos clubes.

Palavras chave: Futebol. Relatório de pesquisa. Etnografia

Resumen: Basado en tres meses de trabajo de campo con el equipo femenino del Santos Fútbol Club, este artículo considera cómo negocian las jugadoras las tensiones entre las inventadas tradiciones de género y la inclusión femenina en el club. Utilizando el concepto de Tradiciones Inventadas de Hobsbawm y adaptando la noción desarrollada por Billig de Nacionalismo Banal a la idea de Patriarcado Banal, el artículo explora las experiencias de las jugadoras en uno de los más emblemáticos equipos de Brasil. Al paso que los hombres dejan de tener el monopolio sobre los clubes oficiales de fútbol, esta investigación concluye que la incorporación del capital cultural acumulado del fútbol femenino a clubes como el Santos es imprescindible para desestabilizar la percepción de tradición e historia eminentemente masculina de los clubes.

Palabras clave: Fútbol. Informe de investigación. Etnografía. 


\section{USE LICENSE}

This article is published for open access under the Creative Commons International Attributions 4.0 (CC BY 4.0) license, which allows use, distribution, and reproduction in any medium, provided that the original work is properly cited. More information at: http://creativecommons.org/licenses/by/4.0

\section{CONFLICT OF INTERESTS}

The authors have declared that this work involves no conflict of interest.

\section{AUTHORS' CONTRIBUTIONS}

Mark Biram: responsible for theentire article

\section{ACKNOWLEDGMENT}

I am very grateful to Francielly Rocha Dossin, who translated this text, which was originally written in English. Without your contribution, this publication would not be possible.

\section{FUNDING}

I really appreciate the help of the Bristol Brazil Fund.

\section{HOW TO CITE}

BIRAM, Mark Daniel. Mermaids in the land of the king: an ethnography of santos fc women. Movimento (Porto Alegre), v. 27, e27005, Jan./Dec. 2021. Available at: https://seer.ufrgs.br/Movimento/article/view/109357. Accessed on [day] [abbreviated month]. [year]. DOI: https://doi.org/10.22456/1982-8918.109357

\section{EDITORIAL BOARD}

Alex Branco Fraga*, Elisandro Schultz Wittizorecki*, Ivone Job*, Mauro Myskiw*, Raquel da Silveira*, Silvana Vilodre Goellner*

*Universidade Federal do Rio Grande do Sul, Escola de Educação Física, Fisioterapia e Dança, Porto Alegre, RS, Brazil 